\title{
Acoustic and Auditory-Perceptual Characteristics of Korean Stop Consonants in Patients with Idiopathic Parkinson's Disease and Cerebellar-Multiple System Atrophy
}

\author{
Bo Mi Kimª, Seok Chae Rhee ${ }^{\mathrm{b}}$, Sung Rae Cho ${ }^{\mathrm{c}}$, HyangHee Kimª, \\ ${ }^{a}$ Graduate Program in Speech and Language Pathology, Yonsei University, Seoul, Korea \\ ${ }^{b}$ Department of English Language and Literature, Yonsei University, Seoul, Korea \\ 'Department and Research Institute of Rehabilitation Medicine, Yonsei University College of Medicine, Seoul, Korea
}

\author{
Correspondence: HyangHee Kim, PhD \\ Graduate Program in Speech and Language \\ Pathology, Yonsei University College of Medicine, \\ 11-12 Yondaedongmun-gil, Seodaemun-gu, Seoul \\ 03721, Korea \\ Tel: +82-2-2228-3900 \\ Fax: +82-2-2227-7984 \\ E-mail: h.kim@yonsei.ac.kr
}

Received: October 20, 2020

Revised: November 16, 2020

Accepted: November 16, 2020

This manuscript is based on the master's thesis of the first author from Yonsei University.

This work was supported by the Ministry of Education of the Republic of Korea and the National Research Foundation of Korea (No. NRF2017S1A5A2A01025920).

\begin{abstract}
Objectives: This study aims to investigate Korean stop consonant production in patients with idiopathic Parkinson's disease (IPD) and Multiple System Atrophy-cerebellar variant (MSA-C) in aiding in differentiating the two types of diseases with Parkinsonism in common. Method: We included a total of 30 subjects (M: $F=15: 15)$ (10 with IPD, 10 with MSA-C, 10 age-matched normals). The subjects were to produce nine Korean stops, $/ \mathrm{p} /, / \mathrm{p}^{\prime} /, / \mathrm{p}^{\mathrm{h}} /$, $/ \mathrm{t} /, / \mathrm{t}^{\prime} /, / \mathrm{t}^{\mathrm{h}} /, / \mathrm{k} /, / \mathrm{k}^{\prime} /, / \mathrm{k}^{\mathrm{h} /}$ embedded in VCV contexts. The speech data were analyzed with the Praat program, and the analyses included length and ratio of closure sections and aspiration sections; speech rate, variability across repeated measurements; and error patterns based on auditory-perceptual evaluation. Results: The MSA-C group demonstrated a significantly longer duration than IPD and normal control groups in closure and aspiration sections in seven and two consonants, respectively. Within the combined closure and aspiration sections, the IPD group showed a significantly higher aspiration duration ratio for all the aspirated consonants $/ \mathrm{p}^{\mathrm{h}} /, 1 \mathrm{t}^{\mathrm{h}} /, / \mathrm{k}^{\mathrm{h}} /$ than MSA-C and normal control groups. The MSA-C group frequently manifested substitution errors of lax consonants with tense or aspirated consonants. The IPD group substituted dental plosives with velar plosives. Conclusion: Difficulty in coordinating between the laryngeal and articulatory gestures in MSA-C and IPD groups is differentially manifested in absolute and relative measures of duration of closure and aspiration segments in stop consonants. In addition, the reduced laryngeal-articulatory movements appeared auditory-perceptually as erroneous substitutions of lax consonants with tense or aspirated consonants. Further studies are warranted to investigate more diverse severities of patients with high volume recruitment.
\end{abstract}

Keywords: Parkinson's disease (PD), Cerebellar variant of multiple system atrophy (MSA-C), Korean stops, Closure duration, Aspiration duration 파킨슨증(parkinsonism)은 떨림(tremor), 서동(bradykinesia), 자세 불안정(postural instability), 강직(rigidity) 증세를 포함하며 특발성 파킨슨병(idiopathic Parkinson's disease, IPD)에서 보이는 대표적인 이상 운동 증상이다(Brooks, 2002; Jankovic, 2008). 그러 나, 질환의 원인이나 기전이 IPD와는 다른 다계통위축증(Multiple System Atrophy, MSA)에서도 세포 내에 루이체(Lewy bodies) 단
백질이 비정상적으로 축적되어 파킨슨증이 관찰된다. 이러한 유사 증상의 출현은 IPD와 $\mathrm{MSA}$ 환자군 간의 감별 진단을 어렵게 한다 (Kim, Chung, Lee, \& Kwon, 2014; van Rumund et al., 2018). 실제 로 임상에서 IPD로 진단되었던 환자 중 약 $15-20 \%$ 정도가 사후 부 검에서 MSA로 판명되었다(van Rumund et al., 2018; Wenning \& Stefanova, 2009). 
$\mathrm{MSA}$ 는 주 증상에 따라 $58 \%$ 정도는 선조흑질변성(striatonigral degeneration) (MSA-Parkinsonian variant, MSA-P)으로, 그리고 $42 \%$ 는 소뇌변성(cerebellar degeneration) (MSA-cerebellar variant, MSA-C) 유형으로 분류된다(Stefanova, Bücke, Duerr, \& Wenning, 2009). 그 중에서도 MSA-C 유형은 IPD에 비해 소뇌 징 후가 우월하게 나타나고, 파킨슨증을 완화하기 위해 복용하는 레 보도파(levodopa) 약물에 대한 반응도가 낮다(Lyoo, Lee, Yoo, \& Lee, 2006). 또한, 자율신경계 검사상의 문제가 더욱 관찰된다는 점 을 감별에 적용하고 있다(Flabeau, Meissner, \& Tison, 2010; Stefanova et al., 2009). 그러나, 자율신경 이상 증상이 경미하거나 파킨 슨증만 보일 경우에는 이러한 감별 요인이 많은 도움이 되지 못한 다(Courbon et al., 2003). 게다가, MSA-C 환자의 50\% 이상이 운동 장애가 나타난 뒤 5년 이내에 Hoehn \& Yahr stage IV 이상으로 진 행되므로(Lyoo et al., 2006; Müller et al., 2000) 질환의 관리를 어떻 게 하느냐에 따라 진행 및 생존 여부에 영향을 미치게 된다(Watanabe et al., 2002). 이에, 빠르고 효율적인 감별을 위한 다양한 시도 가 이루어져 왔다. 선행 연구들은 임상적 특성(Lyoo et al., 2006; Watanabe et al., 2002) 이외에도 말 장애에서 보이는 차이 또한 유 용한 감별 정보가 될 수 있음을 시사한 바 있다(Rusz et al., 2015). $\mathrm{IPD}$ 와 MSA-C 환자군의 90-100\%가 말 장애를 동반하게 되는데 두 질환은 말 속도(Kim, Lee, Lee, \& Kim, 2003) 및 마비말장애 유 형(Kim et al., 2014; Kim \& Kim, 2010)에서 구별되는 특징을 보였 다. 조음 측면 또한, 말 산출 기관의 협응 능력이 저하됨에 따라 다 양한 자음에서 오류를 보이는데 IPD 환자군에서 파열음의 성대진 동 시작시간(Voice Onset Time, VOT)은 가장 자주 사용되는 파라 미터로서 비교적 많은 보고가 이루어졌다(Özsancak, Auzou, Jan, \& Hannequin, 2001; Tykalova, Rusz, Klempir, Cmejla, \& Ruzicka, 2017). 파열음은 개방 전에 구강 폐쇄가 일어나는 폐쇄 구간(closure duration)과 이후에 이어지는 성대 진동이 시작되기 전의 구 간, 즉 기식 구간(aspiration duration)으로 나뉘며, 기식 구간을 음 성학적 측면에서 VOT라 칭한다(Seo, 2002). VOT는 한국어를 포 함하여 여러 언어들의 파열음 지각에 중요한 역할을 하는데 후두 및 상 후두 기관 간의 조절 문제는 VOT 값에 영향을 미친다 $(\mathrm{Au}-$ zou et al., 2000; Lisker \& Abramson, 1964). IPD 환자군의 VOT 길 이는 길어지거나(Novotný, Rusz, Čmejla, \& Růžička, 2014), 변화가 없거나(Harel, Cannizzaro, Cohen, Reilly, \& Snyder, 2004) 감소된 다(Flint, Black, Campbell-Taylor, Gailey, \& Levinton, 1992)고 보 고하여 불일치를 보이지만 이들은 후두근의 운동이 저하됨에 따라 정상 화자에 비해 파열음의 폐쇄 구간은 유의하게 짧아지고 폐쇄 구간의 비율 역시 작아지나 기식 구간은 유의하게 길어졌다(Fisch- er \& Goberman, 2010; Park, Hashimato et al., 2006). 또한, 영어와 같이 유·무성 파열음으로 대립되는 언어에서 MSA 환자군의 무성 파열음 VOT가 IPD 환자군에 비해 훨씬 더 긴 편이었고, 유성 파열 음의 VOT는 현저히 짧아져 청지각적 오류가 증가된 반면, IPD는 정상군과 유사한 양상을 보였다(Tykalova et al., 2017) 또한, MSA$\mathrm{C}$ 환자군이 조음 시 포먼트 전이 및 음절 또는 단어 내 위치한 자음 군과 모음핵, 휴지(pause)가 길어짐에 따라(Duffy, 2005) 시간 조절 의 어려움이 뚜렷하게 관찰되는(Ackermann \& Hertrich, 1997) 것 으로 보아파열음 조음 시 두 질환 간의 특성은 다를 것으로 예측된 다. 그러나, 대부분의 연구는 영어권 환자를 대상으로 하였기 때문 에 우리말 파열음의 특수성을 반영하는 데는 한계가 있다.

한국어의 파열음은 질적 측면에서 영어를 비롯한 다른 언어들이 보편적으로 갖는 유무성 대립 없이 무성음으로만 이루어져 있다 (Lee, 2020). 음운론적으로는 후두에서 일어나는 발성의 유형, 즉 조음 시 성문을 통해 분출되는 기의 유무와 성대의 긴장 여부에 따 라 [-aspirated, -tense]의 평음, [-aspirated, +tense]의 경음, [+aspirated, +tense]인 격음의 삼중 대립 체계를 갖는다(Kwon, 2018). 이 에, 한 가지 조음 위치에서 무성 '평음:유기음:격음'의 서로 다른 세 가지 후두 자질(laryngeal feature)이 대립하게 된다. 그리하여, 미국 영어를 사용하는 IPD 환자보다 한국어를 사용하는 IPD 환자가 파 열음의 기식 구간 조절에 어려움을 보여 말 명료도에 더 큰 영향을 받았다(Kim \& Choi, 2017). 몇몇 선행 연구를 통해 한국어 파열음 의 '삼중 대립'과 관련하여 마비말장애 유형에 따른 특성(Kim \& Kim, 2009) 및 IPD 환자군의 음향학적(Park, Hashimoto et al., 2006), 질적 분석(Park, Itoh et al., 2006)이 이루어졌으나, IPD와 MSA-C 두 집단 간의 비교 연구는 턱없이 부족하다. 이에, 본 연구 에서는 두 환자군 간의 파열음 산출 특성을 조음 위치(양순, 치조, 연구개)에서 세 가지 발성 유형(평음, 경음, 격음)에 따라 음향학적 및 청지각적 측면에서 살펴보고, 집단 간 특성이 감별 요인으로 활 용될 수 있는지 가능성을 알아보고자 한다.

\section{연구방법}

\section{연구대상}

대상자는 서울과 경기 지역에 거주하는 정상군(10명)과 IPD 환 자군(10명) 및 MSA-C 환자군(10명)을 포함한 총 30명이었으며, 평 가 시작 전에 모든 대상자에게 구두와 서면 동의를 받았다. IPD 환 자군은 의학적 진단명이 파킨슨병으로서 질병분류코드(ICD10 코 드)가 G20이고, 고졸 이상 학력이며, 연령 평균(土 표준편차)은 62.7 ( \pm 9.52$)$ 세, 발병 후 경과 기간(post onset time, POT) 평균 $( \pm$ 표준 
편차)은 8.55 ( \pm 5.18)년이었다. Hoehn and Yahr stage (H \& Y stage) 는 신경과 또는 재활의학과 전문의에 의해 주어진 정보를 기준으로, stage I은 3명, stage II는 5명, stage III은 1명, stage IV는 1명이었다. MSA-C 환자군은 의학적 진단명이 소뇌성 다계통위축증(MSA$\mathrm{C}$ ), 올리브뇌교소뇌위축증(olivopontocerebellar atrophy, OPCA), 또는 소뇌위축증(cerebellar atrophy, CA)인 경우였으며, 연령 평균 ( \pm 표준편차)은 58.6 ( \pm 3.86 )세였고, $\mathrm{POT}$ 평균( \pm 표준편차)은 4.5 (3.13 \pm )년이었다. 보행 능력은 본인과 보호자가 판단한 정도와 검사자가 관찰한 것을 바탕으로 기술되었다. 정상군은 $\mathrm{IPD}$ 환자군, MSA-C 환자군과 거주 지역, 성별 및 연령(57.50 \pm 11.23$)$ 이 대응되 는, 의사소통 상에 문제가 없는 표준어 사용자를 대상으로 하였으 며, 세 군간 연령 차이는 없었다(Table 1).

\section{연구방법}

\section{말 자료 및 수집 절차}

자연스러운 발화와 비슷한 환경을 구성하기 위해 ‘이건 / $/ \mathrm{VC}(\mathrm{p} /$, $\left./ \mathrm{t} /, / \mathrm{k} /, / \mathrm{p}^{\prime} /, / \mathrm{t}^{\prime} /, / \mathrm{k}^{\prime} /, / \mathrm{p}^{\mathrm{h}} /, / \mathrm{t}^{\mathrm{h}} /, / \mathrm{k}^{\mathrm{h}} /\right) \mathrm{V} /$ 에요'라는 틀문장을 사용하였 다. 평소의 자연스러운 말 속도로 총 9 개의 틀문장을 3 회 반복하였 으며 1 인당 총 297 개의 문장을 수집하였다. 심이 필요한 경우, 주어 와 파열음 음절 사이에서만 쉬도록 하여 어중 초성 위치의 파열음 이 산출되는 구간에서는 띄어 읽는 쉼이 나타나지 않도록 하였다. 녹음은 A1-PRO 보이스레코더를 사용하여 표본 추출률 $48 \mathrm{KHz}$, 양자화 비트 64 환경에서 대상자의 입과 10-15 cm 정도의 거리를 두고 실시하였다. 수집은 조용한 공간(방)에서 이루어졌으며 소요 시간은 10 분 내외였다.

청지각적 평가는 20-40대 사이 연령으로서 청력에 문제가 없는 정상 성인 10 명에 의하여 단어확인검사(word identification) 방법 으로 실시되었다. 3 회 반복해서 수집된 틀문장 중에서 두 번째에 산 출한 문장을 음향 편집 프로그램 Gold-wave version 5.67을 사용하 여 추출하였다. 소음이 없는 조용한 공간(방)에서 평가자 각각에게 발화 수집 목적을 설명하였고 제공한 기록지에 들리는 그대로 파열 음의 초성을 기록하도록 하였다. 음성은 무작위로 배열하여 들려주 었으며 다시 듣기는 최대 3 회 허용하였다. 약 15 분 내외 소요되었다.

\section{분석 방법}

음향학적 분석은 Praat 6.0.47을 사용하여 표본추출률 22.050 $\mathrm{Hz}$, 양자화 비트 16 환경에서 폐쇄 구간과 기식 구간을 모두 측정하 기에 용이한 /VCV/의 어중 초성 위치의 산출 길이를 분석하였다. 파형(waveform)과 스펙트로그램 화면에서 폐쇄 구간은 '선행 모음 의 포만트 구조가 관찰되다가 갑자기 음향 에너지가 낮아져 스펙트
Table 1. Demographic information of the participants

\begin{tabular}{|c|c|c|c|c|c|c|}
\hline Dx & No. & Sex & Age (yr) & $\begin{array}{c}\text { РОТ } \\
\text { (yr; mon.) }\end{array}$ & $\begin{array}{l}\text { Post-Med. } \\
\text { (hr) }\end{array}$ & $\begin{array}{l}\mathrm{H} \& Y \\
\text { stage }\end{array}$ \\
\hline \multirow[t]{10}{*}{ IPD } & 1 & $\mathrm{~F}$ & 46 & $9 ; 6$ & 2 & II \\
\hline & 2 & $\mathrm{~F}$ & 64 & $1 ; 11$ & 3 & I \\
\hline & 3 & $\mathrm{~F}$ & 72 & $11 ; 11$ & 1 & $\|$ \\
\hline & 4 & $M$ & 68 & $4 ; 8$ & 1.5 & $\|$ \\
\hline & 5 & $\mathrm{~F}$ & 67 & $2 ; 7$ & 8 & I \\
\hline & 6 & $\mathrm{M}$ & 61 & $16 ; 0$ & 1 & IV \\
\hline & 7 & $\mathrm{M}$ & 63 & $9 ; 10$ & 2 & $\|$ \\
\hline & 8 & $\mathrm{~F}$ & 47 & $3 ; 3$ & 3 & I \\
\hline & 9 & $\mathrm{M}$ & 64 & $1 ; 5$ & 4 & $\|$ \\
\hline & 10 & $\mathrm{M}$ & 75 & $11 ; 4$ & 4 & III \\
\hline \multirow[t]{10}{*}{ MSA-C } & 1 & $\mathrm{M}$ & 55 & 7 & & \\
\hline & 2 & $F$ & 62 & $2 ; 3$ & & \\
\hline & 3 & $\mathrm{~F}$ & 54 & $4 ; 9$ & & \\
\hline & 4 & $M$ & 66 & $2 ; 5$ & & \\
\hline & 5 & $F$ & 58 & $4 ; 9$ & & \\
\hline & 6 & $F$ & 55 & 5 & & \\
\hline & 7 & $M$ & 60 & $2 ; 8$ & & \\
\hline & 8 & $M$ & 56 & $3 ; 2$ & & \\
\hline & 9 & $\mathrm{M}$ & 62 & $3 ; 1$ & & \\
\hline & 10 & $M$ & 75 & 10;0 & & \\
\hline \multirow[t]{10}{*}{$\mathrm{NC}$} & 1 & $F$ & 50 & & & \\
\hline & 2 & $F$ & 70 & & & \\
\hline & 3 & $\mathrm{M}$ & 66 & & & \\
\hline & 4 & $F$ & 59 & & & \\
\hline & 5 & $M$ & 61 & & & \\
\hline & 6 & $\mathrm{~F}$ & 42 & & & \\
\hline & 7 & $M$ & 62 & & & \\
\hline & 8 & $\mathrm{M}$ & 73 & & & \\
\hline & 9 & $\mathrm{~F}$ & 46 & & & \\
\hline & 10 & $M$ & 44 & & & \\
\hline
\end{tabular}

$\mathrm{Dx}=$ diagnosis; $\mathrm{yr}=$ years; mon= months; $\mathrm{IPD}=$ idiopathic Parkinson's disease; MSA$\mathrm{C}=$ multiple system atrophy-cerebellar variant; Post-Med. $=$ time after medication; $\mathrm{NC}=$ normal control; $\mathrm{H} \& \mathrm{Y}$ stage $=$ Hoehn and $Y$ ahr stage $($ stages $\mid \sim V) ; \mathrm{h}=$ hours .

로그램상에서 흰 구간으로 관찰되는 부분'으로 간주하였다(Lee, 1996). 기식 구간은 후행 모음의 F1, F2 포먼트가 나타나는, 즉 주기 를 갖춘 파형이 나타나는 구간까지 포함하였다. 또한 모든 분석은 영교차(zero-crossing) 지점에서 실시하여 일관성을 도모하였다.

청지각적 분석은 20 대 3 명, 30 대 4 명, 40 대 3 명으로 총 10 명의 일 반인 청자가 1 인당 270 개의 문장을 듣고 기록지에 작성하였다. 이 결과를 바탕으로 정·오반응과 오류 유형 및 빈도를 분석하였다.

\section{신뢰도 분석}

음향학적 분석의 신뢰도는 총 1,620 개의 폐쇄 구간과 기식 구간 중에 $10 \%$ 인 81 개의 폐쇄 구간과 81 개의 기식 구간을 재분석하여 
도출하였다. 평가자 간 신뢰도는 본 연구자를 제 1 평가자로 설정하 였고, 언어병리학을 전공하고 석사를 졸업한 1 급 언어재활사 1 명을 제2평가자로 설정하였다. Paired $t$-test 검정을 실시한 결과, 폐쇄 구 간 $(p=.177)$, 기식 구간 $(p=.113)$ 모두에서 $p$-value가 .05 이상으로 서 평가자 간 측정치에 차이가 없었다. 평가자 내 신뢰도를 알아보 기 위해 paired $t$-test 검정을 실시한 결과, 폐쇄 구간 $(p=.167)$, 기식 구간 $(p=.326)$ 모두에서 $p$-value가 .05 이상으로서 평가자 내 측정 치에 차이가 없었다.

청지각적 분석의 평가자 간 신뢰도는 세 집단에서 무작위로 15 명 을 선정하여 비교하였다. 그 결과, Chronbach's $\alpha$ 계수는 .983이었 다. 청지각적 분석의 평가자 내 신뢰도는 첫 평가로부터 30 일 후 5 인 의 평가자가 재평가를 실시하였다. 그 결과, Chronbach's $\alpha$ 계수는 .748이었다.

\section{통계 분석}

SPSS 프로그램(version 25.0)을 사용하여 통계 검정을 실시하였 다. 먼저 기술 통계를 이용하여 양순음, 치조음, 연구개음 세 조음 위치에서 연음, 경음, 격음 발성 유형에 따른 폐쇄 구간과 기식 구간 의 3 회 실시한 평균을 산출하였다. 평균을 바탕으로 일원분산분석 을 실시하여 집단 간, 집단 내 조음 방법과 조음 위치에 따른 폐쇄 구간과 기식 구간 길이 및 비율 간의 관계를 살펴보았다. 분석은 유 의 수준이 .05 미만일 때 통계적으로 유의하다고 판정하였고, 유의 한차이가 있는 경우 쉐페(Scheffé) 사후 검정을 실시하였다.

\section{연구결과}

\section{파열음의 음향학적 평가}

폐쇄 구간 길이

IPD 환자군, MSD-C 환자군, 정상군 세 군 간의 폐쇄 구간 길이 를 비교한 결과, 총 9 개의 파열음 중에 경음 치조음 $\left(/ \mathrm{t}^{\prime} /\right)$ 과 연구개음 (//k')을 제외한 7 개 파열음 $/ \mathrm{p} /, / \mathrm{t} /, / \mathrm{k} /, / \mathrm{p}^{\prime} /, / \mathrm{p}^{\mathrm{h}} /, / \mathrm{t}^{\mathrm{h}} /, / \mathrm{k}^{\mathrm{h}} /$ 에서 MSA$\mathrm{C}$ 환자군의 폐쇄 구간들이 IPD 환자군이나 정상군에 비해 유의하 게 길었다(Table 2). 구체적으로는, 평음의 양순음 $/ \mathrm{p} /$ 는 MSA-C 환

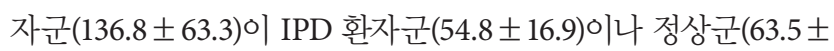
9.6)보다 유의하게 길었다 $(p<.01)$, 평음 치조음 / $\mathrm{t} /$ 또한 MSA-C 환 자군(98.2 \pm 31.2$)$ 이 IPD 환자군(62.1 \pm 18.3$)$ 이나 정상군(61.2 \pm $8.2)$ 보다 유의하게 길었고 $(p<.01)$, 평음 연구개음 $/ \mathrm{k} /$ 도 MSA-C 환 자군(108.5 \pm 28.9$)$ 이 IPD 환자군(76.4 \pm 25.1$)$ 이나 정상군(59.7 \pm $16.9)$ 보다 유의하게 길었다 $(p<.01)$. 경음의 양순음 $/ p^{\prime} /$ 역시, MSA$\mathrm{C}$ 환자군(203.4 \pm 50.1$)$ 이 IPD 환자군(147.6 \pm 32.5$)$ 이나 정상군 $(159.5 \pm 18.5)$ 보다 유의하게 길었다 $(p<.01)$. 격음도 양순음 $/ \mathrm{p}^{\mathrm{h}} /$ 에 서 MSA-C 환자군(181.7 \pm 59.4$)$ 이 IPD 환자군(118.6 \pm 26.4$)$ 이나 정상군(137.4 \pm 31.2$)$ 보다 유의하게 길었고 $(p<.01)$, 치조음 $/ \mathrm{t}^{\mathrm{h}} /$ 에서 도 MSA-C 환자군(165.1 \pm 40.9$)$ 이 IPD 환자군(122.2 \pm 40.7$)$ 이나 정상군(130.3 \pm 18.9$)$ 보다 유의하게 길었으며 $(p<.05)$, 연구개음 $/ \mathrm{k}^{\mathrm{h}} /$ 역시 MSA-C 환자군(151.3 \pm 38.1$)$ 이 IPD 환자군(107.7 \pm 27.5$)$ 이나 정상군(128.4 \pm 20.7$)$ 보다 유의하게 길었다 $(p<.05)$.

Table 2. Comparison of closure duration of Korean stops among the three groups (unit=msec.)

\begin{tabular}{|c|c|c|c|c|c|c|c|}
\hline \multirow{2}{*}{ Manner of phonation } & \multirow{2}{*}{\multicolumn{2}{|c|}{ Place of articulation }} & \multicolumn{3}{|c|}{ Groups } & \multirow{2}{*}{$p$} & \multirow{2}{*}{ Scheffé } \\
\hline & & & IPD & MSA-C & $\mathrm{NC}$ & & \\
\hline \multirow[t]{4}{*}{ Lax } & Bilabial & $/ \mathrm{p} /$ & $54.8 \pm 16.9$ & $136.8 \pm 63.3$ & $63.5 \pm 9.6$ & $.000^{* *}$ & $\mathrm{~N}=\mathrm{I}<\mathrm{M}$ \\
\hline & Alveolar & $/ t /$ & $62.1 \pm 18.3$ & $98.2 \pm 31.2$ & $61.2 \pm 8.2$ & $.001^{* *}$ & $\mathrm{~N}=\mathrm{I}<\mathrm{M}$ \\
\hline & Velar & /k/ & $76.4 \pm 25.1$ & $108.5 \pm 28.9$ & $59.7 \pm 16.9$ & $.000^{* *}$ & $\mathrm{~N}=\mathrm{I}<\mathrm{M}$ \\
\hline & Total & & $64.4 \pm 20.1$ & $114.5 \pm 41.1$ & $61.5 \pm 11.5$ & & \\
\hline \multirow[t]{4}{*}{ Tense } & Bilabial & $/ p^{\prime} /$ & $147.6 \pm 32.5$ & $203.4 \pm 50.1$ & $159.5 \pm 18.5$ & $.005^{* *}$ & $N=\mid<M$ \\
\hline & Alveolar & $/ t^{\prime} /$ & $149.4 \pm 42.2$ & $177.1 \pm 42.5$ & $154.9 \pm 22.4$ & .227 & \\
\hline & Velar & /k'/ & $133.5 \pm 32.6$ & $155.7 \pm 48.0$ & $151.8 \pm 27.6$ & .373 & \\
\hline & Total & & $143.5 \pm 35.8$ & $178.7 \pm 46.9$ & $155.4 \pm 22.8$ & & \\
\hline \multirow[t]{4}{*}{ Aspirated } & Bilabial & $/ \mathrm{p}^{\mathrm{h}} /$ & $118.6 \pm 26.4$ & $181.7 \pm 59.4$ & $137.4 \pm 31.2$ & $.007^{* *}$ & $\mathrm{~N}=\mathrm{I}<\mathrm{M}$ \\
\hline & Alveolar & $/ t^{\mathrm{h}} /$ & $122.2 \pm 40.7$ & $165.1 \pm 40.9$ & $130.3 \pm 18.9$ & $.025^{*}$ & $\mathrm{~N}=\mathrm{I}<\mathrm{M}$ \\
\hline & Velar & $/ k^{\mathrm{h}} /$ & $107.7 \pm 27.5$ & $151.3 \pm 38.1$ & $128.4 \pm 20.7$ & $.011^{*}$ & $\mathrm{~N}=\mathrm{I}<\mathrm{M}$ \\
\hline & Total & & $116.1 \pm 31.5$ & $166.1 \pm 46.2$ & $132.0 \pm 23.6$ & & \\
\hline
\end{tabular}

Values are presented as mean $\pm S D$.

$\mathrm{IPD}=$ idiopathic Parkinson's disease; MSA-C= multiple system atrophy-cerebellar variant; $\mathrm{NC}=$ normal control. ${ }^{*} p<.05,{ }^{* *} p<.01$. 


\section{기식 구간 길이}

세 군의 기식 구간 길이를 비교한 결과, 총 9개의 파열음 비교 중 에서 2개 파열음의 비교에서만 군 간 차이를 보였다(Table 3). 구체 적으로는, 평음 연구개음인 / $/ \mathrm{k}$ 에서 MSA-C 환자군(34.8 \pm 15.4$)$ 이 IPD 환자군(29.3 \pm 13.1$)$ 이나 정상군(17.1 \pm 7.2$)$ 에 비해 유의하게 길 었다 $(p<.05)$. 경음 연구개음인 $/ \mathrm{k}^{\prime} /$ 의 경우에도 MSA-C 환자군 (35.4 \pm 26.5$)$ 이 IPD 환자군(21.0 \pm 5.3$)$ 이나 정상군(15.2 \pm 5.4$)$ 에 비해 유의하게 길었다 $(p<.05)$. 세 집단 모두 조음 방법이 기식성 자 질을 가진 격음 $/ \mathrm{p}^{\mathrm{h}} /, / \mathrm{t}^{\mathrm{h}} /, / \mathrm{k}^{\mathrm{h}} /$ 에서 평균 기식 구간 평균 길이가 가장
길었으며, 조음 위치의 경우에는 가장 후방인 연구개음 $\left(/ \mathrm{k} /, / \mathrm{k}^{\prime} /\right.$, $\left./ \mathrm{k}^{\mathrm{h}} /\right)$ 의 기식 구간 평균 길이가 가장 길었다.

\section{폐쇄 구간+기식 구간 중 기식 구간 비율}

폐쇄 구간과 기식 구간을 합한 길이 중에 기식 구간이 차지하는 비율은 격음의 양순음 $/ \mathrm{p}^{\mathrm{h}} /$, 치조음 $/ \mathrm{t}^{\mathrm{h}} /$, 연구개음 $/ \mathrm{k}^{\mathrm{h}} /$ 각각에서 IPD 환자군이 MSA-C 환자군이나 정상군에 비해 유의하게 높았 다 $(p<.05)($ Table 4$)$. 구체적으로 $/ \mathrm{p}^{\mathrm{h}} /$ 의 기식 구간은 IPD 환자군 (31.4\%)이 MSA-C 환자군(23.7\%)이나 정상군(20.7\%)보다 각각 유

Table 3. Comparison of aspiration duration of Korean stops among the three groups (unit=msec.)

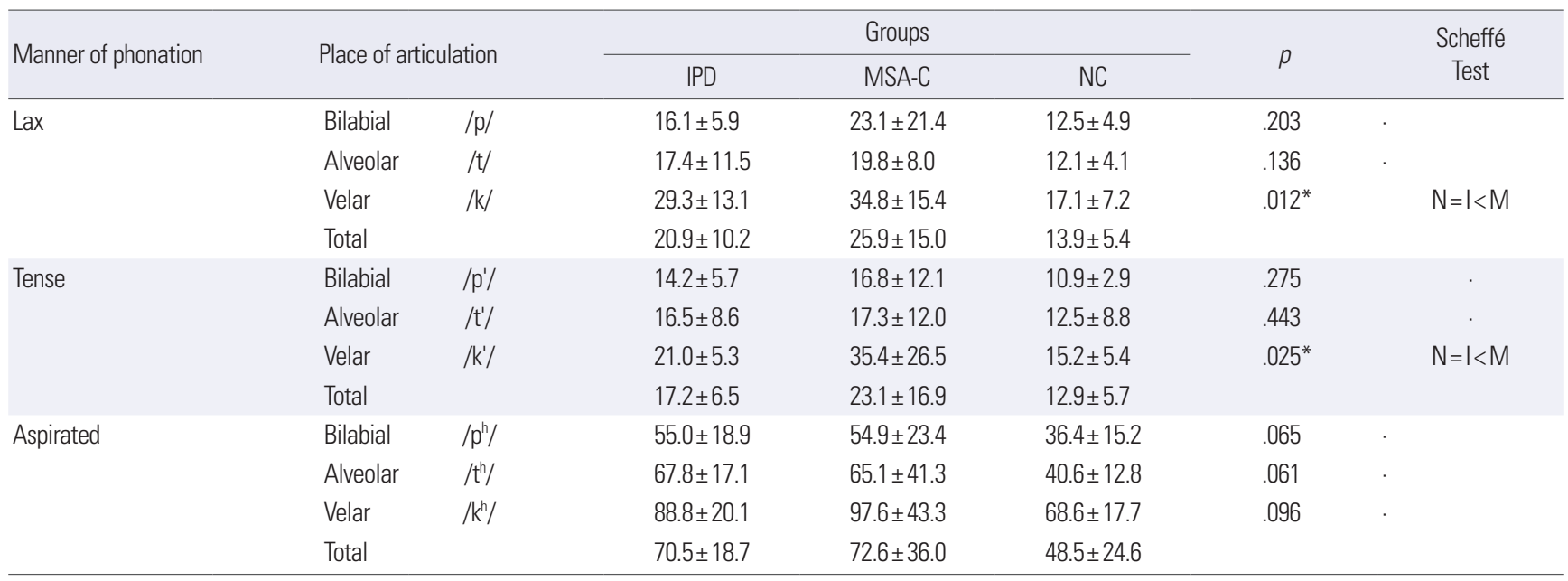

Values are presented as mean $\pm S D$.

$\mathrm{IPD}=$ idiopathic Parkinson's disease; $\mathrm{MSA}-\mathrm{C}=$ multiple system atrophy-cerebellar variant; $\mathrm{NC}=$ normal control.

${ }^{*} p<.05$.

Table 4. Comparison of aspiration duration ratio of the Korean stops among the three groups (unit= \%)

\begin{tabular}{|c|c|c|c|c|c|c|c|}
\hline \multirow{2}{*}{ Manner of phonation } & \multirow{2}{*}{\multicolumn{2}{|c|}{ Place of articulation }} & \multicolumn{3}{|c|}{ Groups } & \multirow{2}{*}{$p$} & \multirow{2}{*}{ Scheffé Test } \\
\hline & & & IPD & MSA-C & NC & & \\
\hline \multirow[t]{4}{*}{ Aspirated } & Bilabial & $/ \mathrm{p}^{\mathrm{h}} /$ & $31.4( \pm 9.0)$ & $23.7( \pm 9.5)$ & $20.7( \pm 6.4)$ & $.024^{*}$ & $\mathrm{~N}=\mathrm{M}<\mathrm{l}$ \\
\hline & Alveolar & $/ \mathrm{t}^{\mathrm{h}} /$ & $36.5( \pm 7.7)$ & $27.0( \pm 13.5)$ & $23.8( \pm 7.2)$ & $.022^{*}$ & $N=M<1$ \\
\hline & Velar & $/ \mathrm{k}^{\mathrm{h}} /$ & $45.4( \pm 6.9)$ & $38.2( \pm 10.7)$ & $34.6( \pm 6.5)$ & $.022^{*}$ & $\mathrm{~N}=\mathrm{M}<1$ \\
\hline & Total & & $37.7( \pm 7.8)$ & $29.6( \pm 11.2)$ & $26.3( \pm 6.7)$ & & \\
\hline \multirow[t]{4}{*}{ Tense } & Bilabial & $/ p^{\prime} /$ & $8.9( \pm 3.3)$ & $7.5( \pm 4.0)$ & $6.4( \pm 1.5)$ & .224 & \\
\hline & Alveolar & $/ t^{\prime} /$ & $10.4( \pm 5.2)$ & $8.9( \pm 5.5)$ & $7.5( \pm 2.5)$ & .403 & \\
\hline & Velar & $/ k^{\prime} /$ & $14.0( \pm 4.1)$ & $17.8( \pm 10.0)$ & $9.3( \pm 3.0)$ & $.025^{*}$ & $\mathrm{~N}=\mathrm{I}<\mathrm{M}$ \\
\hline & Total & & $11.1( \pm 4.2)$ & $11.4( \pm 6.5)$ & $7.7( \pm 5.1)$ & & \\
\hline \multirow[t]{4}{*}{ Lax } & Bilabial & $/ p /$ & $23.4( \pm 8.8)$ & $14.7( \pm 9.6)$ & $16.5( \pm 6.2)$ & .067 & \\
\hline & Alveolar & $/ t /$ & $20.8( \pm 7.4)$ & $17.5( \pm 7.9)$ & $16.2( \pm 3.6)$ & .300 & \\
\hline & Velar & /k/ & $28.2( \pm 12.3)$ & $24.1( \pm 8.2)$ & $22.6( \pm 7.8)$ & .419 & \\
\hline & Total & & $24.1( \pm 9.5)$ & $18.7( \pm 8.5)$ & $18.4( \pm 5.8)$ & & \\
\hline
\end{tabular}

Values are presented as mean \pm SD.

$\mathrm{IPD}=$ idiopathic Parkinson's disease; MSA-C= multiple system atrophy-cerebellar variant; $\mathrm{NC}=$ normal control.

${ }^{*} p<.05$. 
Table 5. Number and rate of errors in stops production among the three groups (unit= count, percentage)

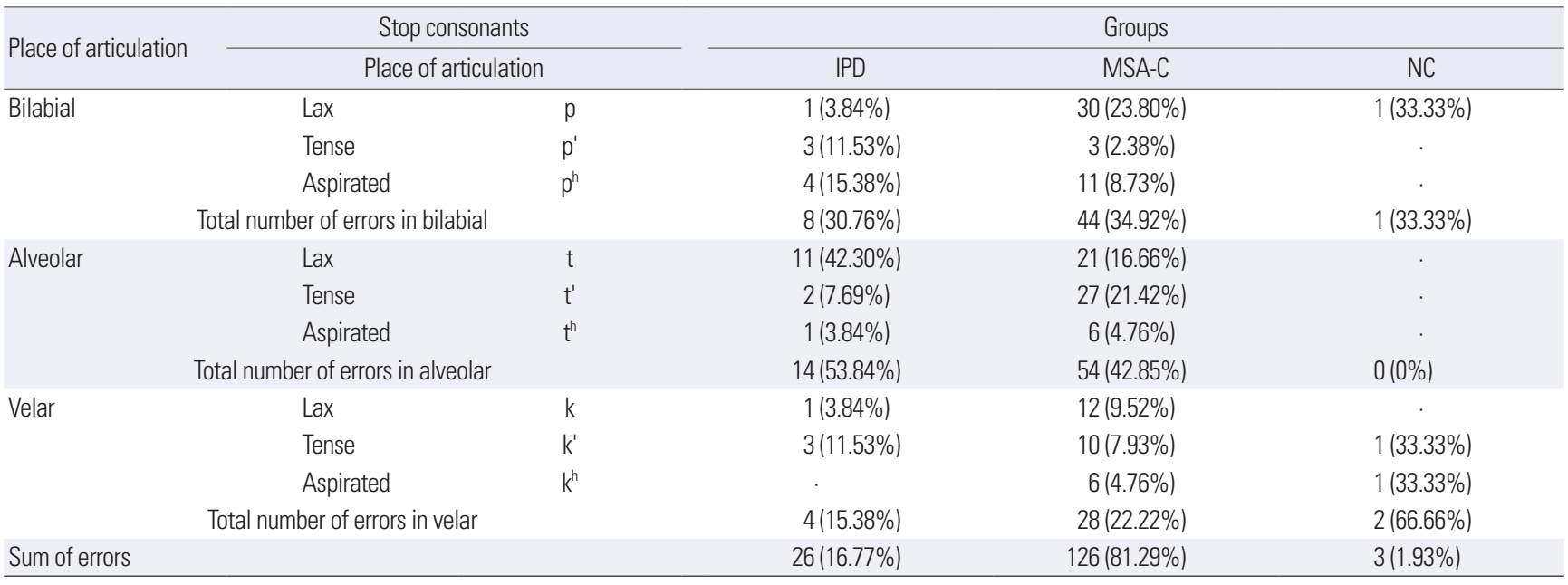

Values are presented as count (percentage).

IPD = idiopathic Parkinson's disease; MSA-C= multiple system atrophy-cerebellar variant; $\mathrm{NC}=$ normal control.

Table 6. Number of substitution errors in stops production among the three groups (unit= count)

\begin{tabular}{|c|c|c|c|c|}
\hline \multirow{2}{*}{ Type of errors } & \multirow{2}{*}{ Stop consonants } & \multicolumn{3}{|c|}{ Groups } \\
\hline & & IPD & MSA-C & NC \\
\hline \multirow{13}{*}{$\begin{array}{l}\text { Manner of } \\
\text { articulation }\end{array}$} & Lax $\rightarrow$ Tense & $p \rightarrow p^{\prime}(4)$ & $p \rightarrow p^{\prime}(21)$ & \\
\hline & & & $t \rightarrow t^{\prime}(18)$ & \\
\hline & & & $k \rightarrow k^{\prime}(10)$ & \\
\hline & Tense $\rightarrow$ Aspirated & $p^{h} \rightarrow p^{\prime}(2)$ & $t^{\prime} \rightarrow t^{h}(22)$ & $k^{\prime} \rightarrow k^{h}(1)$ \\
\hline & & & $\begin{array}{l}k^{\prime} \rightarrow k^{h}(10), \\
p^{\prime} \rightarrow p^{h}(2)\end{array}$ & \\
\hline & Aspirated $\rightarrow$ Tense & $k^{h} \rightarrow k^{\prime}(1)$ & $p^{h} \rightarrow p^{\prime}(11)$ & \\
\hline & & & $t^{h} \rightarrow t^{\prime}(6)$ & \\
\hline & & & $k^{h} \rightarrow k^{\prime}(6)$ & \\
\hline & Lax $\rightarrow$ Aspirated & & $p \rightarrow p^{h}(8)$ & . \\
\hline & & & $t \rightarrow t^{h}(3)$, & \\
\hline & & & $k \rightarrow k^{h}(1)$ & \\
\hline & Tense $\rightarrow$ Lax & & $t^{\prime} \rightarrow t(3)$ & . \\
\hline & Total & -7 & -121 & -1 \\
\hline \multirow{9}{*}{$\begin{array}{l}\text { Place of } \\
\text { articulation }\end{array}$} & Alveolar $\rightarrow$ Velar & $t \rightarrow k(11)$ & $t^{\prime} \rightarrow k^{\prime}(2)$ & \\
\hline & & $t^{\prime} \rightarrow k^{\prime}(2)$ & & \\
\hline & Bilabial $\rightarrow$ Alveolar & $p^{\prime} \rightarrow t^{\prime}(1)$ & $p^{\prime} \rightarrow t^{\prime}(1)$ & $p \rightarrow t(1)$, \\
\hline & & & & $p^{h} \rightarrow t^{h}(1)$ \\
\hline & Bilabial $\rightarrow$ Velar & $p \rightarrow k(1)$ & $p \rightarrow k(1)$ & \\
\hline & Alveolar $\rightarrow$ Bilabial & $t \rightarrow p(1)$ & & \\
\hline & Velar $\rightarrow$ Bilabial & $k^{\prime} \rightarrow p^{\prime}(1)$ & $k \rightarrow p(1)$ & \\
\hline & Velar $\rightarrow$ Alveolar & $\begin{array}{c}k^{\prime} \rightarrow p^{\prime}(1) \\
k \rightarrow t(1)\end{array}$ & & \\
\hline & Total & -19 & -5 & -2 \\
\hline \multirow{3}{*}{$\begin{array}{c}\text { Manner \& Place } \\
\text { of articulation }\end{array}$} & & & $t \rightarrow p^{\prime}(4)$, & \\
\hline & & & $p \rightarrow k^{\prime}(1)$ & \\
\hline & Total & 0 & -5 & 0 \\
\hline
\end{tabular}

IPD = idiopathic Parkinson's disease; MSA-C=multiple system atrophy-cerebellar variant; $\mathrm{NC}=$ normal control.
의하게 높았다 $(p<.05) . / \mathrm{t}^{\mathrm{h}} /$ 의 경우 역시, IPD 환자군(36.5\%)이 MSA-C 환자군(27.0\%)이나 정상군(23.8\%)보다 유의하게 높았다 $(p<.05) . / \mathrm{k}^{\mathrm{h}} /$ 의 기식 구간 역시, IPD 환자군(45.4\%)이 MSA-C 환 자군(38.2\%)이나 정상군(34.6\%)보다 유의하게 높았다 $(p<.05)$. 경 음의 경우는 연구개음 $/ \mathrm{k}^{\prime} /$ 에서만 군 간 차이를 보였는데, MSA-C 환자군(17.8\%)이 IPD 환자군(14.0\%)이나 정상군(9.3\%)에 비해 기 식 구간 비율이 유의하게 높았다 $(p<.05)$.

\section{파열음의 청지각적 평가}

청자의 주관적인 평가를 통해 나타난 IPD 환자군, MSA-C 환자 군, 정상군 간의 대치 오류를 확인한 결과, 총 900 개의 파열 자음 가 운데 MSA-C가 총 126회(14\%)라는 가장 많은 대치 오류를 보였다. 반면에 IPD 환자군은 총 26 회(2.89\%)의 대치 오류(율)을, 정상군은 총 3 회(0.34\%)의 대치 오류(율)을 보였다(Table 5).

대치 오류 유형을 살펴보면, MSA-C 환자군은 IPD 환자군과 정 상군에 비해 발성 유형상의 대치가 총 121 회로 가장 많았고, IPD 환 자군은 7 회, 정상군은 1 회이었다. 이에 반해, 조음 위치상의 오류는 $\mathrm{IPD}$ 가 총 19 회로 가장 많았고, MSA-C 환자군은 5회, 정상군은 2 회이었다. 즉, MSA-C 환자군은 주로 평음과 격음이 경음화되는 발 성 유형상의 오류가 많았고 IPD 환자군은 치조음이 연구개음화되 는 조음 위치상의 오류가 많았다(Table 6).

\section{논의 및 결론}

$\mathrm{IPD}$ 환자와 MSA-C 환자는 서로 유사하게 파킨슨증을 발현하 
기 때문에 감별 진단이 쉽지 않은 것으로 알려져 있다. 따라서 이들 환자군들이 말 장애 영역에서 특정한 차이점이 밝혀진다면 감별 진단에 도움이 될 수 있다. 특히, 발성과 조음 측면에서의 말 산출 장애는 이들 운동장애 질환에서 흔히 관찰되는 특성이므로 연구 될 가치가 있다. 이에, 본 연구에서는 IPD 환자군과 MSA-C 환자군 간에 조음 방법과 조음 위치를 달리한 총 9 개의 파열음 산출에 있 어서 폐쇄 구간, 기식 구간, 그리고 폐쇄 구간+기식 구간 합 중에서 기식 구간이 차지하는 비율을 확인, 비교하였으며, 그에 따른 결과 와논의점은 다음과 같다.

첫째, 파열음의 폐쇄 구간 길이는 MSA-C 환자군이 IPD 환자군 과 정상군에 비해 $/ \mathrm{p} /, / \mathrm{t} /, / \mathrm{k} /, / \mathrm{p}^{\mathrm{p}} /, / \mathrm{p}^{\mathrm{h}} /, / \mathrm{t}^{\mathrm{h}} /, / \mathrm{k}^{\mathrm{h}} /$ 에서 유의하게 길었 고, IPD 환자군과 정상군 간에는 차이가 없었다. 기식 구간 길이는 평음 연구개음인 / $/ \mathrm{k}$ 와 경음 연구개음인 / $\mathrm{k}^{\prime} /$ 에서만 MSA-C 환자군 이 IPD 환자군과 정상군에 비해 유의하게 길었다. 길이가 길다는 것은 폐쇄와 기식 구간에서 머문 시간이 길어져 느리게 산출되었 음을 의미한다. 이처럼, MSA-C 환자군의 조음 동작이 느려지는 원 인으로 첫째, 성대 근육이 접촉하는 폐쇄 구간에서 근긴장이 감소 되어 근력의 생성 및 적절한 수축이 원활히 이루어지지 않거나 둘 째, 성대의 개·폐쇄와 함께 세 위치에서 요구되는 입술, 혀, 연구개 거상 움직임 사이의 협응에 어려움 때문인 것으로 보인다(Jankovic, 2008). 셋째, 병태생리학 측면에서 소뇌 조절 회로가 손상되어 피질로부터 산출될 발화 정보를 미리 받아 이를 조절하고 다듬는 데 더욱 오랜 시간이 소요되고, 다음 음절을 처리하기 전에 이미 산 출된 말에 대한 감각 피드백이 지연되게 된다(Duffy, 2005). 따라서 이들 환자들의 전반적인 구강 조음기의 운동 속도가 느리고 움직임 에 있어서 많은 노력을 요하게 된다(Saxena, Behari, Kumaran, Goyal, \& Narang, 2014). 또, MSA-C 환자군은 경직형(spastic), 실 조형(ataxic), 과소운동형(hypokenetic) 마비말장애의 특성이 단일 적으로 또는 혼합되어 나타난다(Duffy, 2005). 특별히 소뇌나 소뇌 회로 상의 손상에 기인하는 실조형은 음향학적 측면에서 긴 폐쇄 구간과 기식 구간을 나타내며(Kim, Kent, \&Weismer, 2011; Tykalova et al., 2017), 음소를 연장하는(prolonged phonemes) 특성을 보 이고, 청지각적으로도 정상군보다 느린 말 속도를 보인다(Duffy, 2005; Kim \& Kim, 2010). 이는, 방사선 촬영을 통해서도 아랫입술 과 혀의 조음 운동성 저하가 입증된 바 있다(Mcauliffe, Ward, \& Murdoch, 2006).

경음의 기식 구간에서는 연구개의 평음 $/ \mathrm{k} /$ 와 경음 $/ \mathrm{k}^{\prime} /$ 가 유의미 하게 길어졌다. 특히, 경음의 긴장성 자질은 평음과 경음을 변별하 는 중요한 요소일 뿐만 아니라 격음과도 차이를 보이나(Park, Sim, \& Baik, 2005) 성대의 수축 및 근 긴장 능력이 저하(hypotonia)되어 '+constricted glottis' 자질을 갖지 못함을 예측할 수 있다(Duffy, 2005). 연구개음은 성도(vocal tract)에서 조음자(혀)와 조음기(연구 개)의 막음(valving)이 발생하는 부분부터 성문까지의 공간이 양 순음, 치조음에 비해 상대적으로 좁아지고 이러한 구조가 성문 상 압을 증가시켜 VOT를 길어지게 한다(Lee, 1998). VOT는 기식성의 정도와 비례하기 때문에 기식성이 클수록 폐쇄 기간 동안 성대가 멀리 떨어져 있게 되어 파열의 개방 이후 후행하는 모음을 성대가 진동하기까지 더 많은 시간이 소요된다. 이에, 전반적으로 파열의 위치가 후방으로 이동할수록 평균 VOT 값이 증가하는 경향을 보 인다(Seo, 2002). 또한, 말 장애를 보이는 환자군에게 VOT를 측정 하는 이유는 조음 기능 손상을 평가하기 위함으로, VOT가 비정상 적인 경우, 대개는 시간 조절의 손실에 의한 것이지만 성문 개방 크 기, 성문 상압과 하압의 차이(음파 내압) 및 성대 긴장과 같은 다른 변수들 역시 영향을 미친다(Jankovic, 2008). 게다가, 기식 구간은 마비말장애의 중증도와 상당한 연관성을 보이는데, MSA-C 환자 군의 기식 구간이 길다는 것은 IPD 환자군에 비해 마비말장애 중 등도가 심함을 짐작해볼 수 있다(Tykalova et al., 2017).

이와는 대조적으로, IPD 환자군과 정상군 간에는 폐쇄 구간과 기식 구간 각각의 길이에서 모두 유의한 차이가 없었다. 이러한 결 과는 IPD 환자군이 정상 노화과정에서 보이는 말 산출 기제의 해 부 생리적 변화를 비롯하여 운동 조절의 속도와 정확성 저하 등에 따른 조음 문제와 비슷하거나 유의미한 차이가 없다는 결과와 일 치한다. 또, IPD 환자군은 청지각적 및 음향학적 특성이 일반 노인 에게서도 흔하게 발견되므로 '비정상적'이라 간주 되는 몇몇 말 특 성은 나이와 성별을 고려한 정상 규준과 비교했을 때 정상적인 범 주에 속하는 경우도 있다(Kang, Kim, Ban, \& Seong, 2009; Pae, Wang, Choi, Kim, \& Nam, 2005). 그러나, 정상인들은 기능 및 구조 적 변화가 동반되더라도 조음들 간의 협응에 지장이 없지만 IPD 환 자군은 전반적인 신체의 강직으로 인해 복근과 호흡량 그리고 말 생성의 협응을 이루어내지 못하게 된다(Pae et al., 2005). 본 연구결 과 또한, 통계적으로 유의한 차이를 보이지는 않았으나 IPD 환자군 이 정상 대조군에 비해 전체 9 개의 기식 구간에서 평균 길이가 길었 다. 이는, 정상인에 비해 짧은 폐쇄구간과 긴 기식구간 길이를 보인 다는 선행연구들의 보고와 유사하며, 비율 측면에서는 통계적으로 도 유의미하였다.

둘째, 폐쇄 구간+기식 구간에서 기식 구간이 차지하는 비율에 있 어서는, 격음 $/ \mathrm{p}^{\mathrm{h}} /, / \mathrm{t}^{\mathrm{h}} /, / \mathrm{k}^{\mathrm{h}} /$ 에서 IPD 환자군이 MSA-C 환자군과 정 상군에 비해 유의하게 높았다. 기식 구간 비율은 조음 위치, 마비말 장애의 중증도, 말 속도, 약물 복용 여부, 후행하는 모음의 높이에 영향을 받게 되는데 경도 마비말장애의 IPD 환자군에서 기식 구간 
비율이 유의하게 길어진다고 보고된 바 있다(Fischer \& Gober$\operatorname{man}, 2010)$ IPD 환자들은 성도 폐쇄 시 힘의 세기가 감소하고, 성 대 휨으로 인해 폐쇄가 완전히 이루어지지 않게 되며, 후행하는 모 음을 산출하기 위한 성대 진동도 늦어지게 되는데(Jankovic, 2008) 이러한 특성이 성대의 불완전한 폐쇄가 일어나기 쉬운 격음에 영향 을 주어(Park et al., 2005) 기식 구간 비율이 커진 것으로 사료된다.

한편, MSA-C 환자군이 IPD 환자군과 정상군에 비해 연구개 경 음 $/ k^{\prime}$ /의 폐쇄 구간 비율이 유의하게 짧고 기식 구간 비율이 유의하 게 컸다. 앞서 기식 구간 길이에서 언급한 바와 같이 가장 긴 폐쇄 구간과 가장 짧은 기식 구간을 갖는 경음(Park et al., 2005)에서 기 식 구간 비율이 커진 원인으로 성대의 근긴장이 저하(hypotonia)되 어 후두와 후두 상위 조음 기관들의 협착 및 유지에 어려움을 보이 는 것으로 짐작해볼 수 있다. 정리하면, IPD 환자군은 격음의 기식 구간 비율이 유의하게 길어졌고, $\mathrm{MSA}-\mathrm{C}$ 환자군은 연구개 경음의 폐쇄 구간 비율이 유의하게 짧아졌다. 그리고, 이러한 음향학적 특 징은 청지각적으로도 청자가 평음, 경음, 격음을 변별하여 듣는 것 에 어려움을 야기하였다.

청지각적 평가 결과, 전반적인 말 장애의 중증도에 있어서 MSA$\mathrm{C}$ 환자군이 IPD 환자군에 비해 심한 것으로 판단되었다(Tykalova et al, 2017). MSA-C 환자군은 총 131회의 대치 오류가 나타났고, 경 음화가 총 72 회, 격음화가 총 46회 발생하여 조음 방법 오류가 두드 러졌다. 반면에, IPD 환자군은 총 26회 대치 오류를 보였고, 평음에 서 치조 $/ \mathrm{t} /$ 가 연구개 $/ \mathrm{k} /$ 로 대치되는 조음 위치 오류가 두드러졌다.

구체적으로, MSA-C 환자군에서 평음이 동일 위치의 경음 또는 격음으로 대치되는 횟수가 총 61회로 가장 높았다. 음향학적으로 어중 위치에서 폐쇄 시간은 평음과 경음을 구별하는 중요한 지각 단서가 되는데, 평음 '아다’로 인식되는 수치보다 폐쇄 시간이 길어 지면 경음 /아따/로 인식되는 비율이 높아지게 된다(Lee \& Jung, 2000) 게다가, 폐쇄 구간과 기식 구간의 길이가 늘어나 전체 자음의 길이가 길어진 경우에도 경음으로 인식하는 비율이 높아지게 된다 (Lee \& Jung, 2000). 그리하여, 평음이 성대의 긴장 및 협착이 요구 되는 경음으로 산출되는 것은 후두 내재근의 긴장이 제대로 제어 되지 않아 폐쇄 구간과 기식 구간의 운동 능력이 저하됨을 반영하 는 것으로 보인다(Choi \& Choi, 2014). 경음화 다음으로 높은 빈도 를 보인 격음화 오류는 음향학적 측면에서 연구개 경음 $/ \mathrm{k}^{\prime} /$ 와 격음 $/ \mathrm{k}^{\mathrm{h}} /$ 간의 폐쇄 구간 길이 차이가 MSA-C 환자군이 4.31 (土9.83) $\mathrm{msec}$ 로 정상 대조군의 $23.42( \pm 6.89) \mathrm{msec}$, 파킨슨병 환자군의 27.28 ( \pm 1.55$) \mathrm{msec}$ 에 비해 매우 짧았다. 이에, MSA-C 환자군에서 성대의 개·폐쇄가 적절히 이루어 지지 않아 평음이 긴장성 또는 기 식성 자질로 대치됨으로써 삼중 대립에 어려움을 보였다.
반면, IPD 환자군은 음향학적으로 정상군과 유의미한 길이 차 이를 보이지 않았고 격음의 기식 구간에서만 비율이 증가 되었으나, 청지각적으로는 정상군에 비해 약 4 배 이상 많은 오류 빈도를 보였 다. 그리고, 평음 치조 $/ \mathrm{t} /$ 가 연구개 $/ \mathrm{k} /$ 로 대치되는 오류 빈도가 가 장 높게 나타난 것으로 보아 음향학적으로 격음의 기식 구간 비율 이 유의미하게 커지더라도 발성 유형에 따른 평음, 경음, 격음을 생 성하는데 필요한 폐쇄 타이밍의 뚜렷한 차이를 만들 수 있는 것으 로 나타났다(Kim \& Kim, 2019). 그러나, 이러한 조음 위치 오류는 $\mathrm{IPD}$ 환자군에서 기저핵 조절회로가 손상 됨에 따라 프로그래밍된 반응을 유지하거나 반응 사이를 빠르게 전환하는 것이 어렵게 된 다(Tykalova et al, 2017). 또한, 말 구조의 운동 속도 자체는 비교적 정상적이나 혀 움직임의 가동 범위(range of motion, ROM)가 감소 하게 되어 조음점 못미침 현상을 보이게 된다(Mcauliffe et al., 2006). 이에, /터/를 조음하는 동안 혀의 운동 속도는 동일하나 조음 점에 완전히 접촉하지 않은 상태에서 발음하게 되어(Kang, Seong, \& Yoon, 2011), 치조음이 연구개음으로 대치 오류가 두드러진 것으 로 보인다(Kang et al., 2009).

본 연구결과를 통해, 한국어 파열음의 삼중 대립 산출 시 음향학 적 측면에서 MSA-C 환자군은 비정상적으로 긴 폐쇄 구간과 긴 기 식 구간 길이를 보이나 폐쇄 대 기식 구간의 비율은 유지되었다. 반 면, IPD 환자군은 비율에서 짧은 폐쇄 구간 대 긴 기식 구간을 보여 기식성 조절의 어려움이 두드러졌다. 또한, 음향학적 특성이 청지 각에 어떻게 반영되는지를 살펴볼 수 있었는데 IPD 환자들은 치조 음을 연구개음화하는 조음 위치 오류가, MSA-C 환자들은 평음을 경음 또는 격음화 하는 조음 방법 오류가 두드러졌다. 이에, 주된 대 치 오류 유형 또한 변별 요인이 될 수 있음을 시사하였다. 대부분의 언어에서 MSA 환자들이 IPD 환자들에 비하여 전반적인 말속도가 느린 것은 잘 알려진 사실이며(Kim et al., 2003), 이는 본 연구에서 도 확인할 수 있었다. 그리고, 영어를 비롯한 각 언어에서 VOT는 파 열음의 대립에서 중요한 음성적 특징으로 작용하나 한국어의 삼중 대립에서는 긴장성 자질 또한 주요한 변수가 되었으며, 연구개음이 MSA-C 환자군의 성대 협착 성립 여부 및 조음 기관의 운동 능력을 두드러지게 파악할 수 있는 파열음이었다.

본 연구는 9가지 파열음 모두를 대상으로 우리말의 중 대립 구조 를 다루었다. 음향학적 평가를 통해 객관적인 자료를 제시하였으 며, 청지각적 평가를 통해 청취자가 어떻게 인식하는지를 확인하였 다. 이에, 두 환자군의 파열음의 산출 특성을 살펴보고자 할 때 비 교 근거를 제공한다는 점에 의의를 갖는다. 그러나, 본 연구는 다음 과 같은 제한점을 갖는다. 첫째, 환자군의 중증도를 통제하지 않은 적은 수의 IPD와 MSA-C 환자를 대상으로 했기 때문에 두 질환의 
파열음 특성을 대표하기에는 한계가 있다. 둘째, 스펙트로그램 상 에서 나타난 유성성 및 소음(noise) 구간 출현 빈도를 살펴보거나, 조음 오류를 보인 파열음을 분류하여 개별적인 음향 분석을 실시 하지 않았다. 청지각적 평가 또한, 질환의 특성을 반영하는 음성의 질, 운율 등에 대한 질적 분석이 이루어지지 않았다. 그리고, 3 회 반 복 산출하여 수집된 발화에서 특정 환자군에서 특정 파열음의 변 이가 존재하였는데 추후 이러한 불규칙성을 살펴볼 수 있는 후속 연구가 필요하다. 더불어, 의미 단어 또는 자발화 과제 등 실생활과 더욱 연계된 말 자료로 측정한다면 두 질환 간의 특성에 대한 좀 더 세밀한 고찰이 가능할 것으로 보인다.

\section{REFERENCES}

Ackermann, H., \& Hertrich, I. (1997). Voice onset time in ataxic dysarthria. Brain and Language, 56(3), 321-333.

Auzou, P., Ozsancak, C., Morris, R. J., Jan, M., Eustache, F., \& Hannequin, D. (2000). Voice onset time in aphasia, apraxia of speech and dysarthria: a review. Clinical Linguistics \& Phonetics, 14(2), 131-150.

Brooks, D. J. (2002). Diagnosis and management of atypical parkinsonian syndromes. Journal of Neurology, Neurosurgery \& Psychiatry, 72(suppl 1), i10-i16.

Choi, S. H., \& Choi, C. H. (2014). The comparison of aerodynamic measures in Korean stop consonants based on phonation types. Phonetics and Speech Sciences, 6(4), 195-203.

Courbon, F., Brefel-Courbon, C., Thalamas, C., Alibelli, M. J., Berry, I., Montastruc, J. L., ... \& Senard, J. M. (2003). Cardiac MIBG scintigraphy is a sensitive tool for detecting cardiac sympathetic denervation in Parkinson's disease. Movement Disorders, 18(8), 890-897.

Duffy, J. R. (2005). Motor speech disorders: substrates, differential diagnosis, and management (2nd ed.). St. Louis, Mo: Mosby.

Fischer, E., \& Goberman, A. M. (2010). Voice onset time in Parkinson disease. Journal of Communication Disorders, 43(1), 21-34.

Flabeau, O., Meissner, W. G., \& Tison, F. (2010). Multiple system atrophy: current and future approaches to management. Therapeutic Advances in Neurological Disorders, 3(4), 249-263.

Flint, A. J., Black, S. E., Campbell-Taylor, I., Gailey, G. F., \& Levinton, C. (1992). Acoustic analysis in the differentiation of Parkinson's disease and major depression. Journal of Psycholinguistic Research, 21(5), 383-399.

Harel, B. T., Cannizzaro, M. S., Cohen, H., Reilly, N., \& Snyder, P. J. (2004). Acoustic characteristics of Parkinsonian speech: a potential biomarker of early disease progression and treatment. Journal of Neurolinguistics, 17(6), 439-453.

Jankovic, J. (2008). Parkinson's disease: clinical features and diagnosis. Journal of Neurology, Neurosurgery \& Psychiatry, 79(4), 368-376.

Kang, Y., Kim, Y. D., Ban, J. C., \& Seong, C. J. (2009). A comparison of the voice differences of patients with idiopathic Parkinson's disease and a normal-aging group. Phonetics and Speech Sciences, 1(1), 99-107.

Kang, Y., Seong, C. J., \& Yoon, K. C. (2011). A study of prosodic features of patients with idiopathic Parkinson's disease. Phonetics and Speech Sciences, 3(1), 145-151.

Kim, H., Lee, M. S., Lee, W. Y., \& Kim, S. W. (2003). Speech rate analysis of dysarthric patients with Parkinson's disease and multiple system atrophy. Speech Sciences, 10(4), 221-227.

Kim, J. Y., Chung, S. J., Lee, J. H., \& Kwon, M. (2014). Characteristics of dysarthria and cognitive functions in patients with Parkinson's disease and Parkinson-plus syndrome. Communication Sciences \& Disorders, 19(4), 551-557.

Kim, S. W., \& Kim, H. (2009). The senile neurodegenerative dysarthrias. Korean Journal of Communication Disorders, 14(1), 82-94.

Kim, Y., \& Choi, Y. (2017). A cross-language study of acoustic predictors of speech intelligibility in individuals with Parkinson's disease. Journal of Speech, Language, and Hearing Research, 60(9), 2506-2518.

Kim, Y., Kent, R. D., \& Weismer, G. (2011). An acoustic study of the relationships among neurologic disease, dysarthria type, and severity of dysarthria. Journal of Speech, Language, and Hearing Research, 54(2), 417-429.

Kwon, S. M. (2018). A study on teaching methods of Korean plosives considering recent changes in the three-way phonation contrast. Korean Language and Literature, 76, 9-34.

Lee, H. Y. (1996). Korean phonetics. Seoul, Korea: Taehaksa.

Lee, J. H. (2020). Phonological typology of the plosive consonant system in Korean. The Research Society of Language and Literature, 48(2), 5-29.

Lee, K. H., \& Jung, M. S. (2000). Acoustic characteristics and perceptual cues for Korean stops. Speech Sciences, 7(2), 139-155.

Lee, S. H. (1998). On the effects of places articulation of stops on their closure duration in Korean. The Acoustical Society of Korea, 17(6), 8-13.

Lisker, L., \& Abramson, A. S. (1964). A cross-language study of voicing in initial stops: acoustical measurements. Word, 20(3), 384-422.

Lyoo, C. H., Lee, S. Y., Yoo, Y. H., \& Lee, M. S. (2006). The quantitative 18-fluorodeoxyglucose PET study in the differential diagnosis between idiopathic Parkinson's disease and multiple system atrophy. Journal of the 
Korean Neurological Association, 24(1), 31-37.

Mcauliffe, M. J., Ward, E. C., \& Murdoch, B. E. (2006). Speech production in Parkinson's disease: I. An electropalatographic investigation of tonguepalate contact patterns. Clinical Linguistics \& Phonetics, 20(1), 1-18.

Müller, J., Wenning, G. K., Jellinger, K., McKee, A., Poewe, W., \& Litvan, I. (2000). Progression of Hoehn and Yahr stages in Parkinsonian disorders: a clinicopathologic study. Neurology, 55(6), 888-891.

Novotný, M., Rusz, J., Čmejla, R., \& Rủžička, E. (2014). Automatic evaluation of articulatory disorders in Parkinson's disease. IEEE/ACM Transactions on Audio, Speech, and Language Processing, 22(9), 1366-1378.

Özsancak, C., Auzou, P., Jan, M., \& Hannequin, D. (2001). Measurement of voice onset time in dysarthric patients: methodological considerations. Folia Phoniatrica et Logopaedica, 53(1), 48-57.

Pae, K. H., Wang, J. H., Choi, S. H., Kim, S. Y., \& Nam, S. Y. (2005). Glottic characteristics and voice complaint in the elderly. Journal of the Korean Society of Laryngology, Phoniatrics and Logopedics, 16(2), 135-139.

Park, S., Hashimoto, R., Kwon, M., Chung, S. J., \& Kim, S. R. (2006). Acoustic analysis of stop sound production in Korean and Japanese speakers with Parkinson's disease. Korean Journal of Communication \& Disorders, 11(3), 165-178.

Park, S., Itoh M., Hashimoto, R., Kwon, M., Chung, S. J., \& Kim, S. R. (2006). Qualitive acoustic study of Korean stop production in Parkinson's disease. Proceedings of the Korean Speech-Language \& Hearing Association (KSHA), 159-168.

Park, S., Sim, H., \& Baik, J. S. (2005). Production ability for Korean bilabial stops in Parkinson's disease. Journal of Multilingual Communication Disor- ders, 3(2), 90-102.

Rusz, J., Bonnet, C., Klempír, J., Tykalová, T., Baborová, E., Novotný, M., ... \& Růžička, E. (2015). Speech disorders reflect differing pathophysiology in Parkinson's disease, progressive supranuclear palsy and multiple system atrophy. Journal of Neurology, 262(4), 992-1001.

Saxena, M., Behari, M., Kumaran, S. S., Goyal, V., \& Narang, V. (2014). Assessing speech dysfunction using BOLD and acoustic analysis in parkinsonism. Parkinsonism \& Related Disorders, 20(8), 855-861.

Seo, M. K. (2002). An experimental study of voice onset time of Korean stops-correlation with context. Linguistic Studies, 22, 27-45.

Stefanova, N., Bücke, P., Duerr, S., \& Wenning, G. K. (2009). Multiple system atrophy: an update. The Lancet Neurology, 8(12), 1172-1178.

Tykalova, T., Rusz, J., Klempir, J., Cmejla, R., \& Ruzicka, E. (2017). Distinct patterns of imprecise consonant articulation among Parkinson's disease, progressive supranuclear palsy and multiple system atrophy. Brain and Language, 165, 1-9.

van Rumund, A., Aerts, M. B., Esselink, R. A., Meijer, F. J., Verbeek, M. M., \& Bloem, B. R. (2018). Parkinson's Disease Diagnostic Observations (PADDO): study rationale and design of a prospective cohort study for early differentiation of parkinsonism. BMC Neurology, 18(1), 1-7.

Watanabe, H., Saito, Y., Terao, S., Ando, T., Kachi, T., Mukai, E., ... \& Hirayama, M. (2002). Progression and prognosis in multiple system atrophy: an analysis of 230 Japanese patients. Brain, 125(5), 1070-1083.

Wenning, G. K., \& Stefanova, N. (2009). Recent developments in multiple system atrophy. Journal of Neurology, 256(11), 1791-1808. 


\section{국문초록}

\section{특발성 파킨슨병과 소뇌성 다계통위축증 환자 간의 조음 파열음 비교: 음향학적 및 청지각적 특성 김보미 ${ }^{1} \cdot$ 이석재 ${ }^{2} \cdot$ 조성래 ${ }^{3} \cdot$ 김향희 ${ }^{13}$ \\ '연세대학교 대학원 언어병리학협동과정, ${ }^{2}$ 연세대학교 영어영문학과, ${ }^{3}$ 연세대학교 의과대학 재활의학교실 및 재활의학연구소}

배경 및 목적: 파킨슨증을 동반하는 특발성 파킨슨병과 소뇌성 다계통위축증은 후두와 조음 기관 간의 협응 능력이 저하되어 우리말 파열음의 평음, 경음, 격음 산출 시 오류를 야기한다. 이에, 본 연구에서는 두 환자군과 정상군의 파열음 산출 양상을 세 가지 조음 위치 (양순, 치조, 연구개)에서 세 가지 조음 방법(평음, 경음, 격음)에 따라 음향학적 및 청지각적 측면에서 비교해보고 두 환자군 간의 감별 요인으로 활용할 수 있는 특색은 무엇인지 알아보고자 한다. 방법: 연구대상으로는 특발성 파킨슨병(남:여 = 5:5, 평균 나이= $62.7 \pm 9.5$ 세), 소뇌성 다계통위축증 환자군(남:여 $=5: 5$, 평균 나이 $=58.6 \pm 3.8$ 세), 정상군(남:여 $=5: 5$, 평균 나이 $=57.5 \pm 11.2$ 세) 각각 10 명씩 총 30 명을 포함하였다. 문장의 어중 초성 위치에서 전체 9 개 파열음 $/ \mathrm{p} /, / \mathrm{t} /, / \mathrm{k} /, / \mathrm{p}^{\prime} /, / \mathrm{t}^{\prime} /, / \mathrm{k}^{\mathrm{l}} /, / \mathrm{p}^{\mathrm{h}} / / \mathrm{t}^{\mathrm{h}} /, / \mathrm{k}^{\mathrm{h}} /$ 의 폐쇄와 기식 구간의 길이, 폐쇄 와 기식 구간의 비율을 살펴보았고, 청지각적 측면에서는 대치 오류 횟수와 그 유형을 분석하여 음향학적 분석과의 연관성을 알아보았 다. 결과: 첫째, 폐쇄와 기식 구간 길이는 소뇌성 다계통위축증 환자군이 유의하게 길게 나타나 느린 속도를 보였다. 둘째, 폐쇄+기식 구 간에서 기식 구간이 차지하는 비율은 격음에서 특발성 파킨슨병 환자군이 유의하게 길었다. 이에, 기식성이 특발성 파킨슨병 환자군의 파열음 조음에 영향을 미치는 것으로 사료되었다. 반면, 소뇌성 다계통위축증 환자군은 연구개 경음에서 유의하게 짧은 폐쇄 구간과 긴 기식 구간 비율을 보였다. 셋째, 소뇌성 다계통위축증 환자군은 후두의 개 - 폐 속도가 현저하게 느려 평음을 동일한 위치의 경음 또 는 격음화하는 조음 방법 오류가 빈번하였고, 특발성 파킨슨병 환자군은 혀의 움직임이 저하되어 치조 파열음을 연구개 파열음으로 대 치하는 조음 위치 오류가 빈번하였다. 논의 및 결론: MSA-C 환자들과 IPD 환자들은 후두 및 조음 기관의 협응에 어려움으로 파열음 의 삼중대립 산출에 어려움을 보이기는 하나 그 양상은 서로 달랐다. 또한, 주된 대치 오류 유형 또한 변별 요인이 될 수 있음을 시사하 였다. 본 연구는 특발성 파킨슨병과 소뇌성 다계통위축증 환자군의 우리말 파열음의 특성을 객관적 및 주관적 평가를 통해 비교 분석 해 보고, 감별 정보로 활용할 수 있는 차이점은 무엇인지 알아보았다는 점에 의의가 있다.

핵심어: 소뇌성 다계통위축증, 특발성 파킨슨병, 파열음, 폐쇄 구간, 기식 구간

본 논문은 제1저자의 연세대 석사학위논문을 발췌 및 수정한 것임.

이 논문은 2017년 대한민국교육부와한국연구재단의 지원을 받아수행된 연구임(No. NRF-2017S1A5A2A01025920).

\section{참고문헌}

강영애, 김용덕, 반재천, 성철재 (2009). 파킨슨병 환자와 정상 노인의 음성 비교. 말소리와 음성과학, 1(1), 99-107. 강영애, 성철재, 윤규철 (2011). 파킨슨병 환자와 정상 노인 간의 문장 읽기에 나타난 운율 특성 비교. 말소리와 음성과학, 3(1), 145-151. 권성미 (2018). 한국어 3중 대립 파열음의 발성 유형의 변화를 고려한 발음 교육 방안 모색. 어문론총, 76, 9-34. 김선우, 김향희 (2009). 노인 퇴행성 신경 질환의 마비말장애 특성. 언어청각장애연구, 14(1), 82-94.

김자영, 정선주, 이재홍, 권미선 (2014). 특발성 파킨슨병과 파킨슨플러스 증후군 환자의 마비말장애 및 인지기능 특성 비교. Communication Sciences \& Disorders, 19(4), 551-557.

김향희, 이미숙, 이원용, 김선우 (2003). 파킨슨병과 다계통위축증 환자군 간의 말속도 비교평가. 음성과학, 10(4), 221-7. 류철형, 이승엽, 유영훈, 이명식 (2006). 파킨슨병과 다계통위축증 감별 진단에 정량적 18-fluorodeoxyglucose PET의 유용성. 대한신경과학회지, 24(1),31-37.

박성혜, 권미선, 정선주, 김성렬 (2006). 한국과 일본 파킨슨병 화자의 파열음 음향 분석. 언어청각장애연구, 11(3), 165-178. 박성혜, 이토, 권미선, 정선주, 김성렬 (2006). 파킨슨병 화자의 파열음 산출에 대한 질적인 음향 특성에 대한 연구. 한국언어치료학회 학술발표대회 


\section{논문집, 159-168.}

배기훈, 왕종환, 최승호, 김상윤, 남순열 (2005). 노인 환자에서의 음성학적 특성. 대한후두음성언어의학회지, 16(2), 135-139.

서민경 (2002). 한국어 파열음의 VOT에 관한 실험음성학적 연구-환경에 따른 VOT 변이를 중심으로. 언어연구, 22, 27-45.

이경희, 정명숙 (2000). 한국어 파열음의 음향적 특성과 지각 단서. 음성과학, 7(2), 154-170.

이숙향 (1998). 한국어 폐쇄음의 조음 장소가 폐쇄구간의 음성학적 길이에 미치는 영향에 관하여. 한국음향학회지, 17(6), 8-13.

이진호 (2020). 한국어 파열음 체계의 언어 유형론적 고찰. 어문연구, 48(2), 5-29.

이호영 (1996). 국어음성학. 태학사.

최성희, 최철희 (2014). 한국어 파열음의 발성 유형에 따른 공기역학 측정치 비교. 말소리와 음성과학, 6(4), 195-203.

\section{ORCID}

김보미(제1저자, 대학원생 https://orcid.org/0000-0002-3035-8631); 이석재(공동저자, 교수 https://orcid.org/0000-0002-9565-5290);

조성래(공동저자, 교수 https://orcid.org/0000-0003-1429-2684); 김향희(교신저자, 교수 https://orcid.org/0000-0003-4949-2512) 